\title{
Article \\ Arbuscular Mycorrhizal Fungi from Argentinean Highland Puna Soils Unveiled by Propagule Multiplication
}

\author{
Fernanda Covacevich ${ }^{1,2, *}$, Keren Hernández Guijarro ${ }^{2}\left(\mathbb{D}\right.$, Esteban M. Crespo ${ }^{3}$, Erica Lumini ${ }^{4, *(\mathbb{D})}$, \\ María Soledad Rivero Mega ${ }^{3}$ and Mónica A. Lugo ${ }^{3,5}$ (D)
}

1 Instituto de Investigaciones en Biodiversidad y Biotecnología (INBIOTEC-CONICET) Fundación para las Investigaciones Biológicas Aplicadas (FIBA), Mar del Plata 7600, Argentina

2 Instituto Nacional de Tecnología Agropecuaria (INTA), Unidad Integrada Estación Experimental Agropecuaria Balcarce, Balcarce 7620, Argentina; hernandez.keren@inta.gob.ar

3 Micología, Diversidad e Interacciones Fúngicas (MICODIF), Área Ecología, Facultad de Química, Bioquímica y Farmacia, Universidad Nacional de San Luis (UNSL), San Luis 5700, Argentina; ecrespo@unsl.edu.ar (E.M.C.); mariasoledadrivero@sanluis.edu.ar (M.S.R.M.); lugo@unsl.edu.ar (M.A.L.)

4 Institute for Sustainable Plant Protection (IPSP) of National Research Council (CNR), Viale Mattioli 25, 10125 Turin, Italy

5 Instituto Multidisciplinario de Investigaciones Biológicas (IMIBIO-CONICET-UNSL), San Luis 5700, Argentina

* Correspondence: covacevich.fernanda@inta.gob.ar (F.C.); erica.lumini@ipsp.cnr.it (E.L.); Tel.: +54-223-410-2560 (F.C.)

\section{check for} updates

Citation: Covacevich, F.; Hernández Guijarro, K.; Crespo, E.M.; Lumini, E.; Rivero Mega, M.S.; Lugo, M.A. Arbuscular Mycorrhizal Fungi from Argentinean Highland Puna Soils Unveiled by Propagule Multiplication. Plants 2021, 10, 1803. https://doi.org/10.3390/ plants10091803

Academic Editors: Paula Baptista and Livy Williams

Received: 27 July 2021

Accepted: 26 August 2021

Published: 30 August 2021

Publisher's Note: MDPI stays neutral with regard to jurisdictional claims in published maps and institutional affiliations.

Copyright: (c) 2021 by the authors. Licensee MDPI, Basel, Switzerland. This article is an open access article distributed under the terms and conditions of the Creative Commons Attribution (CC BY) license (https:// creativecommons.org/licenses/by/ $4.0 /)$.

\begin{abstract}
Low arbuscular-mycorrhizal (AM) sporulation in arid field soils limits our knowledge of indigenous species when diversity studies are based only on spore morphology. Our aim was to use different approaches (i.e., spore morphological approach and PCR-SSCP (single-strand-conformationpolymorphism) analysis after trap plant multiplication strategies to improve the knowledge of the current richness of glomalean AM fungi (Glomerales; Glomeromycota) from the Argentine Puna. Indigenous propagules from two pristine sites at 3870 and $3370 \mathrm{~m}$ of elevation were multiplied using different host plants; propagation periods (2-6 months), and subculture cycles $(1 ; 2$; or 3$)$ from 5 to 13 months. The propagule multiplication experiment allowed the detection of different glomoid taxa of Funneliformis spp. and Rhizoglomus spp., which were considered cryptic species since they had never been found in Puna soils before. On the other hand; almost all the generalist species previously described were recovered from cultures; except for Glomus ambisporum. Both plant host selection and culture times are critical for Glomerales multiplication. The SSCP analysis complemented the morphological approach and showed a high variability of Glomus at each site; revealing the presence of Funneliformis mosseae. This study demonstrates that AMF trap culture (TC) is a useful strategy for improving the analysis of AM fungal diversity/richness in the Argentinean highlands.
\end{abstract}

Keywords: Glomerales; trap plant multiplication strategy; biodiversity; highlands; single strand conformation polymorphism (SSCP)

\section{Introduction}

Arbuscular mycorrhizal fungi (AMF) favour plant growth by playing an important role in the exchange of nutrients and metabolites. Diversity studies of AMF in this ancient symbiotic relationship are carried out through both classical taxonomy and molecular techniques provide a better understanding of their different functions and roles in ecosystem functioning [1].

AMF diversity has been traditionally assessed by the morphological identification of fungal spores [2]. Nevertheless this methodology poses some difficulties: (i) spore production is highly dependent on AMF physiology and the environment (edaphic and climatic); (ii) some fungi are non-sporulating; and (iii) spores could be parasitized or degraded in the soil [3]. Despite its detractors, AMF trap culture (TC) has been successfully implemented 
to circumvent these problems and to multiply soil AMF propagules under controlled conditions to increase the chances of species detection $[3,4]$ and possibly serve as a source of an accurately identified AMF inoculum. Besides the morphological characterisation of AMF spores, a plethora of molecular techniques has been usefully developed in the last decades that allow the assessment of both AM fungal diversity from different ecosystems (i.e., forest, grassland, rangelands, and agroecosystems) [5] and the genetic diversity of specific AM fungal taxa (i.e., different karyotypes produced by the genus Funneliformis (= Glomus) and the wide interisolate genetic diversity of model AMF such as Rhizophagus irregularis) $[6,7]$. Next-generation sequencing (NGS) allows for better characterization of AMF communities in different ecosystems. However, its cost and the computational capacity needed to process and understand the huge amount of information generated limit the extensive adoption of these techniques. On the other hand, fingerprinting analysis based on DNA banding patterns has been broadly used for decades to unveil the genetic variability of soil microbial communities (i.e., denaturing and temperature gradient gel electrophoresis (DGGE and TGGE, respectively), single-strand conformation polymorphism (SSCP), length heterogeneity-PCR (LH-PCR), terminal-restriction fragment length polymorphism (T-RFLP)). At present, these techniques are still valid due to their high genotypic resolution, low cost and high versatility, reliability and reproducibility. Among these techniques, SSCP has been widely used for both assessing AMF diversity in peculiar environments, such as arid gypsum sites [8], and detecting shifts in soil fungal community structure related to different land uses and agricultural management $[9,10]$. Thus, the use of SSCP could be considered a first approach before deciding to perform NGS.

Despite the growing interest in knowing and safeguarding the biological diversity associated with extreme environments, some biodiversity hotspots such as the Argentine Puna are being increasingly threatened and not extensively investigated. The Puna is a harsh South American biogeographical region characterised by highlands with a desert climate and unique properties, such as a wide daily temperature range, high solar radiation, and particular flora and fauna [11]. AMF diversity has been scarcely studied in this environment [12]. Different AMF indigenous species from field soils at elevations higher than $3320 \mathrm{~m}$ have been identified by means of direct spore isolation and their morphological characterisation [12] without previous propagule multiplication. A low number of AMF spores directly retrieved from field samples and an inverse relationship between AMF spore diversity and height above sea level were found in Puna [12].

This work aims to evaluate the impact of soil propagule multiplication on the diversity and richness of the indigenous glomoid AMF species detectable in two soils of the Puna by comparing the results with those previously obtained, without multiplication, on field soils of the same sites: Abra del Cóndor (AC) and Iturbe (It). We hypothesised that different strategies for soil AMF propagule detection (direct propagule isolation vs TC multiplication) and characterisation (morphological and molecular SSCP approaches) could improve knowledge about the AMF community composition in this extreme environment.

\section{Results and Discussion}

\subsection{Glomoid AMF Diversity Assessed by Spore Morphology}

Spores and sporocarps of glomoid arbuscular mycorrhizal fungi (AMF) were found in all the analysed samples (Figure 1, Table 1, Figure 2, Table 2). Different levels of morphospecies richness of glomoid spores, both with and without funnel shaped pores, were found at each trap culture (TC) multiplication cycle. Glomoid spores, derived from trap substrates (Tables 1 and 2) were found in the form of single spores (Figure 1), in clusters and forming sporocarps, and within old roots and other AMF spores (Figure 2). Eight morphologically distinctive AMF species were retrieved (Tables 1 and 2). All the analysed morphospecies from the Puna soils showed morphometric values lower than those reported for the original descriptions. Spore clusters of Funneliformis sp. (Figure 1a) and F. monosporus (Figure 1c-d) showed morphological and morphometric features similar to Funneliformis mosseae, but the last spore wall did not stain with a Melzer reagent. 


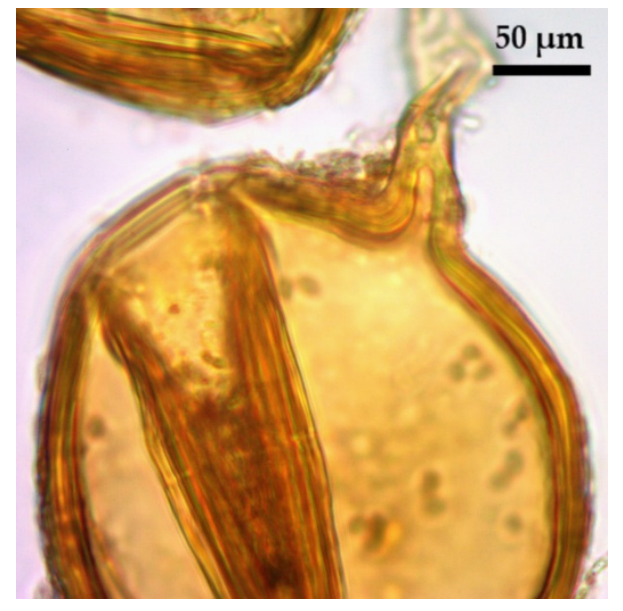

(a)

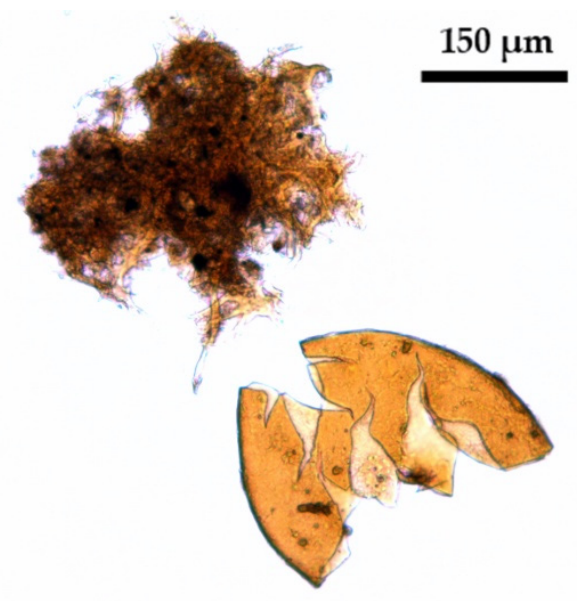

(c)

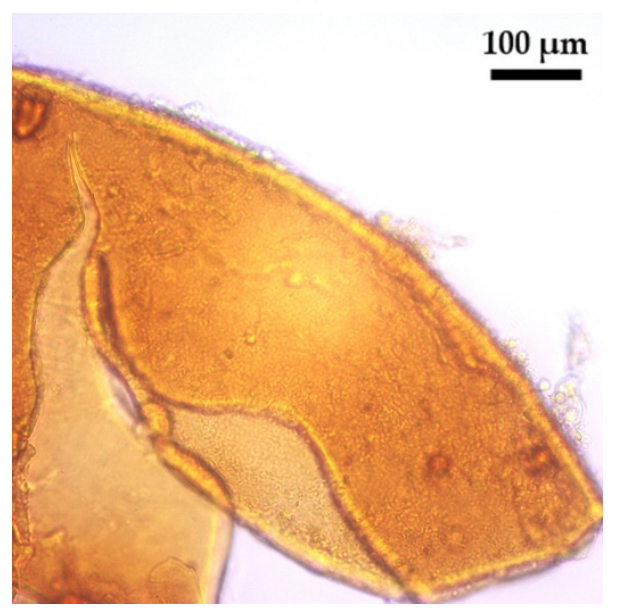

(e)

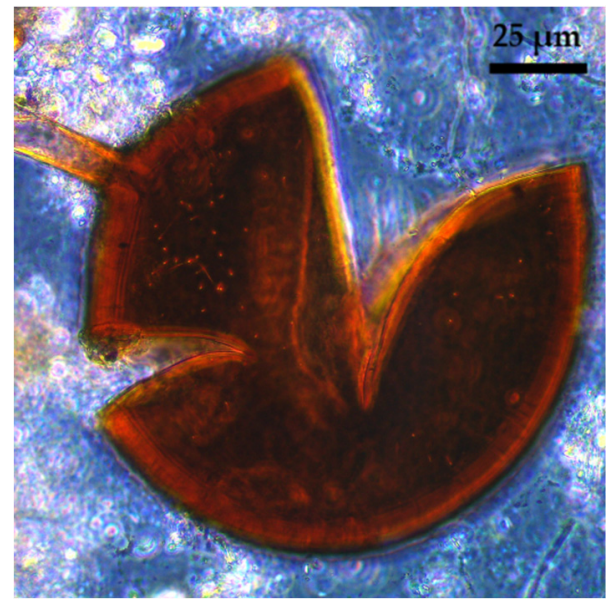

(b)

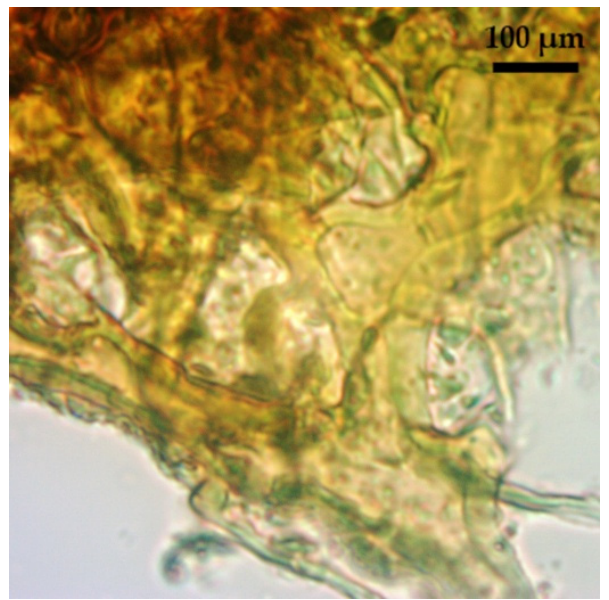

(d)

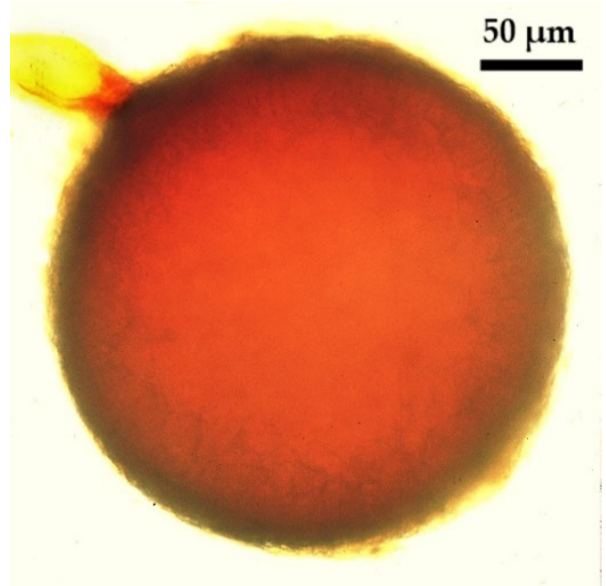

(f)

Figure 1. Glomoid AMF with single spores. (a) Funneliformis sp.; (b) F. geosporus; (c) F. monosporus, general view of the spore and hyphal mantle or peridium; (d) F. monosporus, detail of the hyphal peridium; (e) F. monosporus, detail of wall ornamentations; (f) Septoglomus constrictum. 
Table 1. Description of trap plant culture cycles, glomoid species found and richness assessed at the Puna site Abra del Cóndor.

\begin{tabular}{|c|c|c|c|}
\hline \multicolumn{4}{|c|}{ ABRA DEL CÓNDOR } \\
\hline Trap Culture Strategy & AC Field & ACM1 & ACM2 \\
\hline Sampling site of Puna & Abra del Cóndor & Abra del Cóndor & Abra del Cóndor \\
\hline Site elevation & $3870 \mathrm{~m}$ & $3870 \mathrm{~m}$ & $3870 \mathrm{~m}$ \\
\hline Data source & {$[12]$} & This study & This study \\
\hline $\begin{array}{c}\text { Initial total spore } \\
\text { density/100 g dry soil weight }\end{array}$ & - & 424 & 424 \\
\hline 1st cycle time & - & 5 months & 5 months \\
\hline 1st cycle TPS & - & $\begin{array}{l}\text { Sorghum bicolor }+ \text { Melilotus } \\
\text { albus }\end{array}$ & S. bicolor \\
\hline 2nd cycle time & - & - & 2 months \\
\hline 2nd cycle TPS & - & - & $\begin{array}{c}\text { S. bicolor }+ \text { M. albus }+ \\
\text { Allium ampeloprasum var. } \\
\text { porrum }\end{array}$ \\
\hline Total time of trap culture & - & 5 months & 7 months \\
\hline Glomoid AMF taxa & $\begin{array}{c}\text { Glomus sp. } \\
\text { G. ambisporum } \\
\text { Rhizoglomus aggregatus } \\
\text { (= Glomus aggregatum) } \\
\text { Sclerocystis sinuosa } \\
\text { (= Glomus sinuosum) }\end{array}$ & $\begin{array}{c}\text { Funneliformis sp. } \\
\text { F. geosporus } \\
\text { Sclerocystis sp. } \\
\text { S. sinuosa } \\
\text { Septoglomus constrictum }\end{array}$ & $\begin{array}{l}\text { Funneliformis sp. } \\
\text { F. geosporus } \\
\text { Septoglomus constrictum }\end{array}$ \\
\hline $\begin{array}{l}\text { Richness of glomoid } \\
\text { morphospecies } \\
\text { with funnel pore }\end{array}$ & 0 & 3 & 3 \\
\hline $\begin{array}{c}\text { Richness of total glomoid } \\
\text { morphospecies }\end{array}$ & 4 & 5 & 4 \\
\hline $\begin{array}{l}\mathrm{H}^{\prime} \text { Diversity Index (SSCP } \\
\text { analysis) }\end{array}$ & - & 1.44 & 1.16 \\
\hline $\begin{array}{l}\text { Sequence of an excised band } \\
\text { (SSCP analysis) }\end{array}$ & - & KT950811 & KT950815 \\
\hline
\end{tabular}

AC: Abra del Cóndor; AC Field: Abra del Cóndor soil field samples; ACM1: Abra del Cóndor soil samples with one cycle of trap culture; ACM2: Abra del Cóndor soil samples with two cycles of trap culture; SSCP: single-strand conformation polymorphism; TPS: trap plant species; -: no trap culture was carried out.

The morphospecies Funneliformis geosporus (Figure 1b) was the most frequently found in all TCs, regardless of site (AC or It) or the analysed trap plant species (TPS) combination (Figure S1). However, this morphospecies was not found in field soils from AC (Table 1) or It (Table 2). Generally, F. geosporus is a quickly sporulating species but its spore abundance, both from field soil and TC, varies depending on land use [13] and edaphic properties [14]. In general, some authors suggest that AMF yield spores after 10 weeks of TC multiplication, which is in accordance with the previous two months' report for F. geosporus TC $[13,15]$. This study showed that $F$. geosporus produced spores under the aforementioned multiplication conditions, which reinforces the importance of TC for spore production and the identification of this species in Puna soils. Therefore, F. geosporus was a cryptic AM species concerning Puna field samples but a generalist species in TC as it has been reported after different TC approaches were used in several environments [4,14-16]. In this study, trap culture allowed the development and sporulation of AMF species which otherwise could not have been recovered from field soil. 


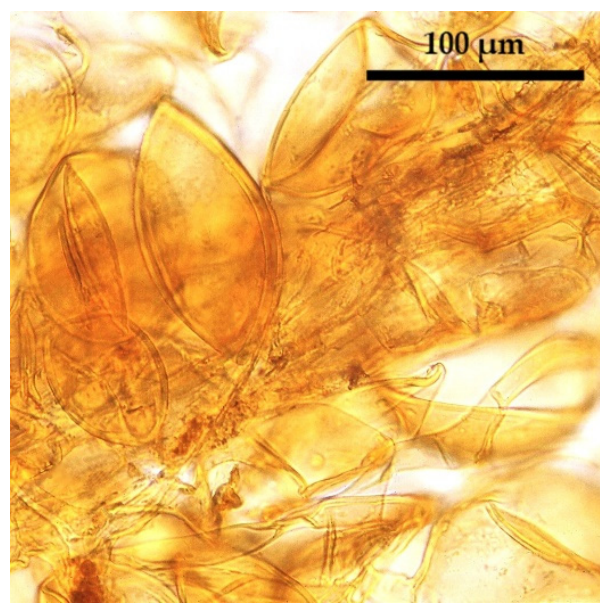

(a)

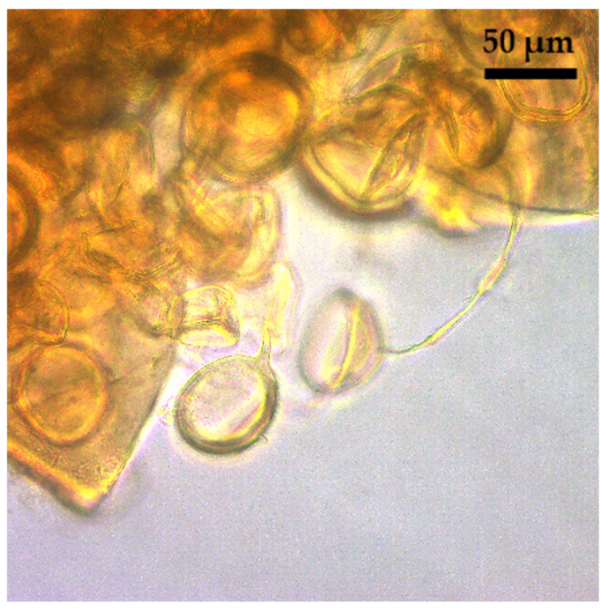

(c)

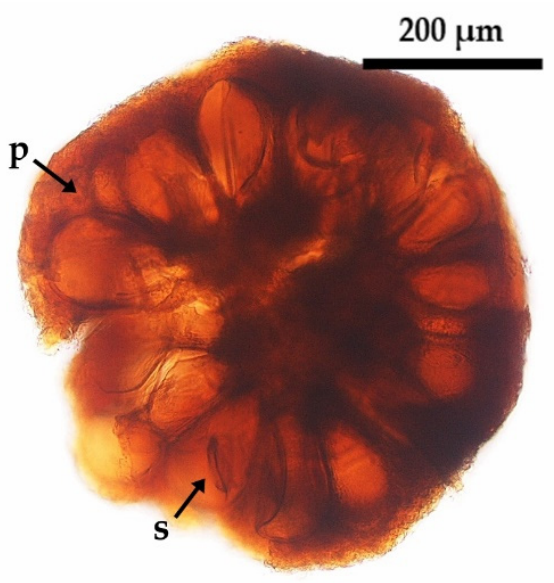

(e)

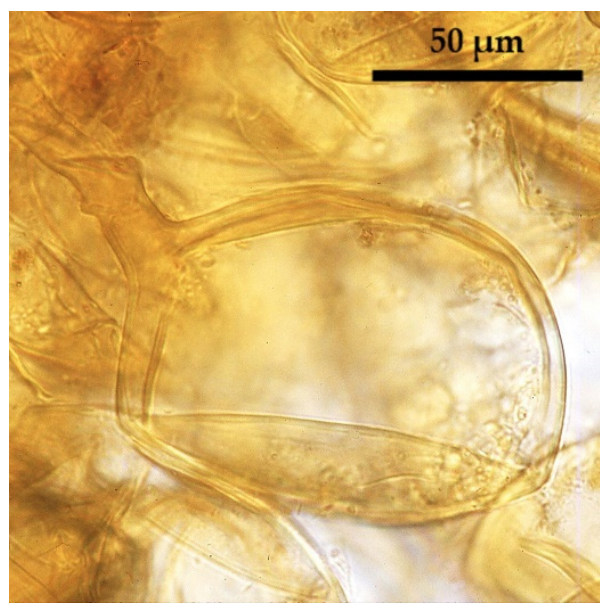

(b)

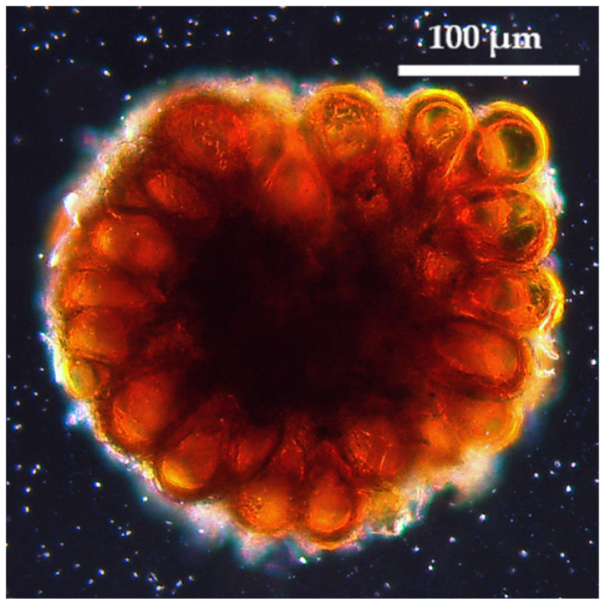

(d)

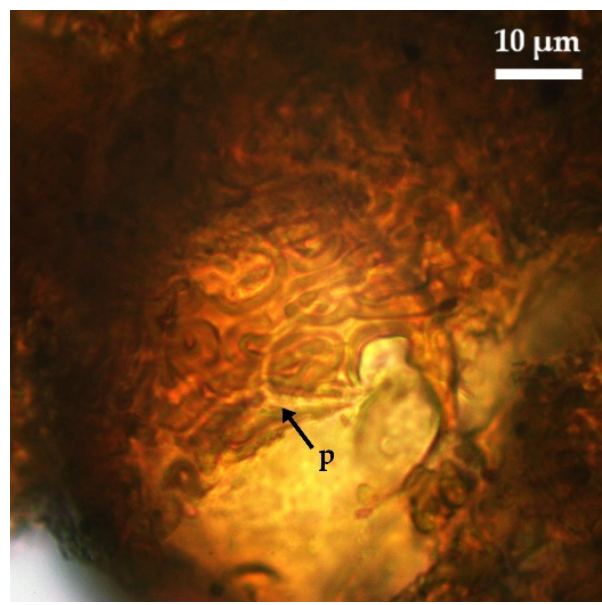

(f)

Figure 2. Glomoid AMF with spores in clusters and sporocarps. (a) Rhizoglomus aggregatus spore cluster in senescent root; (b) R. aggregatus spore with endospore; (c) R. microaggregatum spores inside other AMF spore; (d) Sclerocystis sp., general view of the spores without peridium; (e) S. sinuosa, general view of the spores (s) with peridium (p); (f) S. sinuosa, detail of the hyphal peridium (p). 
Table 2. Description of cycles of trap plant cultures, glomoid species found and richness assessed at Iturbe site of Puna.

\begin{tabular}{|c|c|c|c|c|}
\hline \multicolumn{5}{|c|}{ ITURBE } \\
\hline Trap Culture Strategy & It Field & ItM3-a1 & ItM3-a2 & ItM3-a3 \\
\hline Sampling site of Puna & Iturbe & Iturbe & Iturbe & Iturbe \\
\hline Site elevation & $3370 \mathrm{~m}$ & $3370 \mathrm{~m}$ & $3370 \mathrm{~m}$ & $3370 \mathrm{~m}$ \\
\hline Data source & [12] & This study & This study & This study \\
\hline $\begin{array}{c}\text { Initial total spore } \\
\text { density } / 100 \mathrm{~g} \text { dry soil } \\
\text { weight }\end{array}$ & - & 171 & 171 & 171 \\
\hline 1st cycle time & - & 5 months & 5 months & 5 months \\
\hline 1st cycle TPS & - & $\begin{array}{c}\text { Sorghum bicolor } \\
\text { Melilotus albus } \\
\text { Zea mays } \\
\text { Pennisetum glaucum } \\
\text { Avena sativa } \\
\text { Secale cereale } \\
\text { S. bicolor+ S. cereale } \\
\text { P. glaucum + S. cereale }\end{array}$ & $\begin{array}{c}\text { S. bicolor } \\
\text { M. albus } \\
\text { Z. mays } \\
\text { P. glaucum } \\
\text { A. sativa } \\
\text { S. cereale } \\
\text { S. bicolor }+ \text { S. cereale } \\
\text { P. glaucum }+ \text { S. cereale }\end{array}$ & $\begin{array}{c}\text { S. bicolor } \\
\text { M. albus } \\
\text { Z. mays } \\
\text { P. glaucum } \\
\text { A. sativa } \\
\text { S. cereale } \\
\text { S. bicolor+ S. cereale } \\
\text { P. glaucum+ S. cereale }\end{array}$ \\
\hline 2nd cycle time & - & 6 months & 6 months & 6 months \\
\hline 2nd cycle TPS & - & S. bicolor & S. bicolor & S. bicolor \\
\hline 3rd cycle time & - & 2 months & 2 months & 2 months \\
\hline 3rd cycle TPS & - & $\begin{array}{l}\text { Allium ampeloprasum } \\
\text { var. porrum }\end{array}$ & S. bicolor & M. albus \\
\hline $\begin{array}{l}\text { Total time of trap } \\
\text { culture }\end{array}$ & & 13 months & 13 months & 13 months \\
\hline Glomoid AMF taxa & $\begin{array}{c}\text { Glomus sp. } \\
\text { G. ambisporum } \\
\text { Rhizoglomus aggregatus } \\
\text { (=Glomus aggregatum) } \\
\text { S. sinuosa } \\
\text { (=Glomus sinuosum) }\end{array}$ & $\begin{array}{c}\text { Funneliformis sp. } \\
\text { F. geosporus } \\
\text { F. monosporus } \\
\text { R. aggregatus } \\
\text { R. microaggregatum }\end{array}$ & $\begin{array}{l}\text { Funneliformis sp. } \\
\text { F. geosporus } \\
\text { R. aggregatus } \\
\text { S. sinuosa }\end{array}$ & $\begin{array}{l}\text { F. geosporus } \\
\text { R. microaggregatum } \\
\text { R. aggregatus } \\
\text { S. sinuosa }\end{array}$ \\
\hline $\begin{array}{l}\text { Richness of glomoid } \\
\text { morphospecies } \\
\text { with funnel pore }\end{array}$ & 0 & 2 & 2 & 1 \\
\hline $\begin{array}{l}\text { Richness of total } \\
\text { glomoid } \\
\text { morphospecies }\end{array}$ & 4 & 5 & 4 & 4 \\
\hline $\begin{array}{l}\mathrm{H}^{\prime} \text { Diversity Index } \\
\text { (SSCP analysis) }\end{array}$ & - & 1.46 & 1.52 & 1.54 \\
\hline $\begin{array}{l}\text { Sequence of an excised } \\
\text { band (SSCP analysis) }\end{array}$ & - & KT950814 & KT950813 & KT950812 \\
\hline
\end{tabular}

It: Iturbe; It Field, Iturbe soil field samples; TPS: trap plant species; ItM3-a1: Iturbe soil samples with three cycles of trap culture with Allium ampeloprasum var. porrum as the third TPS; ItM3-a2: Iturbe soil samples with the three cycles of trap culture with Sorghum bicolor as the third TPS; ItM3-a3: Iturbe soil samples with three cycles of trap culture with Melilotus albus as the third TPS; SSCP: single-strand conformation polymorphism; -: no trap culture was carried out.

Septoglomus constrictum (Figure 1f) is another cryptic species recovered only from Abra del Cóndor (AC) soils by means of TC with the $\mathrm{C}_{4}$ grass Sorghum bicolor as TPS in at least one culture cycle (Table 1). S. constrictum has also been reported as a cryptic species for different soils and environments [4] using $2 \mathrm{C}_{4}$ TPS combined with other TPS in multiplication strategies with long-term culture periods in Brazilian tropical soils [4] and Chinese saline and forest soils [15]. However, S. constrictum could not be recovered in an 8-month TC with 4 different TPS that were not $C_{4}$ [13]. Based on this evidence and on the 
fact that AMF sporulation is a host species-dependent process [4], the results suggested that the inclusion of a $C_{4}$ TPS in the TC could be necessary to promote the sporulation of S. constrictum from AC soils. As regards Iturbe (It) soil (Table 2), S. constrictum could not be detected, even when $\mathrm{C}_{4}$ species were used as a TPS. Further investigation should be carried out to determine whether this species recovery is influenced by other factors.

The aggregate-forming morphospecies Rhizoglomus aggregatus (Figure 2a,b) and $R$. microaggregatum (Figure 2c) were detected only in It samples by means of TC. $R$. microaggregatum was not detected either in Abra del Cóndor TC or in Iturbe field samples [12], which suggests that $R$. microaggregatum is another cryptic species revealed by TC. However, taking into account the different results obtained with the three TC strategies used for the It samples (no R. microaggregatum at the soil from ItM3-a2, see Table 2), it can be inferred that subsequent cultivation cycles with $S$. bicolor could inhibit $R$. microaggregatum sporulation. Furthermore, other studies showed that $R$. microaggregatum can be found in field sample soils, but that it cannot be recovered after 5 months of TC that included a single TPS per pot [14]. We therefore suggest that to achieve successful sporulation of R. microaggegatum, a TC strategy should include more than one TPS per TC cycle; several cycles of more than 5 months of cultivation, alternating TPS between cycles; and, in a third cycle, a TPS different from $S$. bicolor.

On the other hand, R. aggregatus (Figure 2a,b) was previously detected in It and AC soil samples [12], but it was not recovered from AC soils by TC in spite of being considered both a cryptic species for tropical areas [4] and a generalist species for field and meadow European soils [13] and Chinese mountains [15]. In these studies, R. aggregatus sporulation in TC was strongly influenced by TPS [14] and it only required an average of 4 months of multiplication $[13,15]$. Our results also reflect this trend in which the use of numerous TPS and a long cultivation period in TC (at least 13 months) promoted the sporulation of R. aggregatus.

Regarding Glomus ambisporum, it was detected in field soils [12], but it could not be recovered with TC multiplication, which was in agreement with previous reports where it was regarded as a common species in field soils but an absent one in TC along diverse environments and trap strategies $[4,13,15]$. Future studies with in vitro culture or direct detection by molecular tools are necessary to detect and isolate G. ambisporum, which has shown to be difficult to culture with the TC methodology.

Two sporocarpic morphospecies of Sclerocystis, Sclerocystis sp. (Figure 2d) and S. sinuosa (Figure 2e,f), were found at the two sites after TC. Nevertheless, S. sinuosa was not detected in any soil sample whenever $A$. ampeloprasum var. porrum was included as a TPS. This result deserves future study as $S$. sinuosa is a generalist AMF in Puna field soils [12]. Moreover, other studies show that, even though S. sinuosa is commonly found in field samples from tropical and Alpine environments [13,14], it could not be recovered by TC. Regardless, the application of TC strategies was successful in promoting S. sinuosa sporulation in Puna soils when the rest of the TPS were used.

\subsection{Molecular Analysis of Glomoid AMF Diversity}

The diversity of glomoid arbuscular mycorrhizal fungi (AMF) indigenous to the Puna soils was assessed through the polymorphism of the 28S rDNA gene using a specific set of primers that amplified representative species of Funneliformis (= Glomus) genus such as F. mosseae, F. caledonius, and F. geosporus [16,17]. The single-strand conformation polymorphism (SSCP) assay revealed the genetic variability of the glomoid AMF in soils from Abra del Cóndor (AC) and Iturbe (It). The number of detected bands ranged between 16 and 38 for all samples. Some band patterns were common to all sites and multiplication strategies, while others were site-specific (Figure 3). 


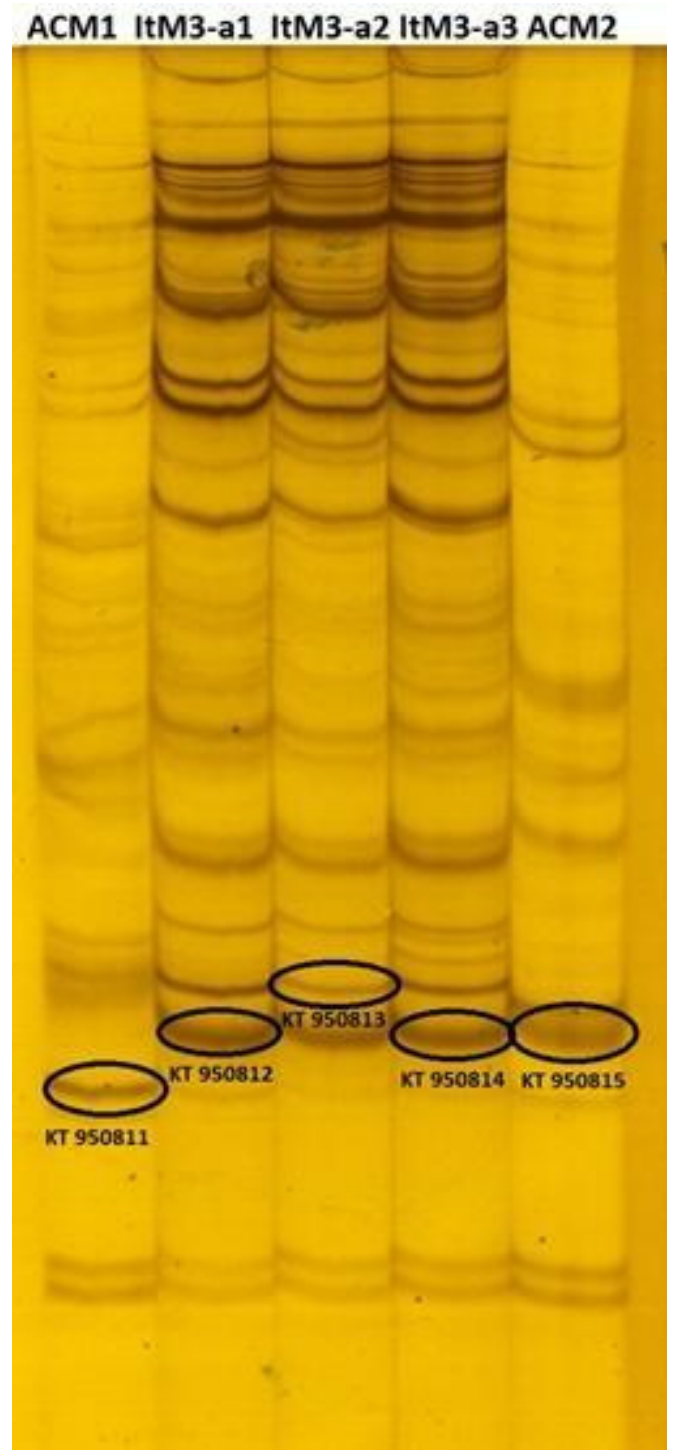

Figure 3. PCR-SSCP patterns obtained from a region of the 28S-rDNA gene of AMF indigenous to the Argentine Puna belonging to Funneliformis genus. References: AC: Abra del Cóndor; It: Iturbe; M1, M2, M3: multiplication cycles 1, 2 and 3, respectively. Bands marked with ovals were cut and sequenced. Access numbers of the sequences are shown on Figure 4.

Richness, which is the number of taxa (phylotype number) per sample, was determined from SSCP fingerprints. For Abra del Cóndor soil, we found 16 phylotypes (distinctive bands) at the ACM2 TC strategy and 29 at the ACM1 (for TC details see Figure S1, Table 1). For the Iturbe soils, we found 32, 36 and 38 phylotypes for strategies ItM3-a1, ItM3-a2 and ItM3-a3, respectively (Figure S1, Table 2). Differences in richness were also reflected in the Shannon-Wiener $\mathrm{H}^{\prime}$ index, which was calculated from the number and intensity of the bands from the pattern generated by the SSCP strategy (Figure 3). Among the soils of Abra del Cóndor, the ACM1 strategy seemed to increase $\mathrm{H}^{\prime}$ diversity, while for the Iturbe soil the $\mathrm{H}^{\prime}$ index was similar among all TC strategies. 


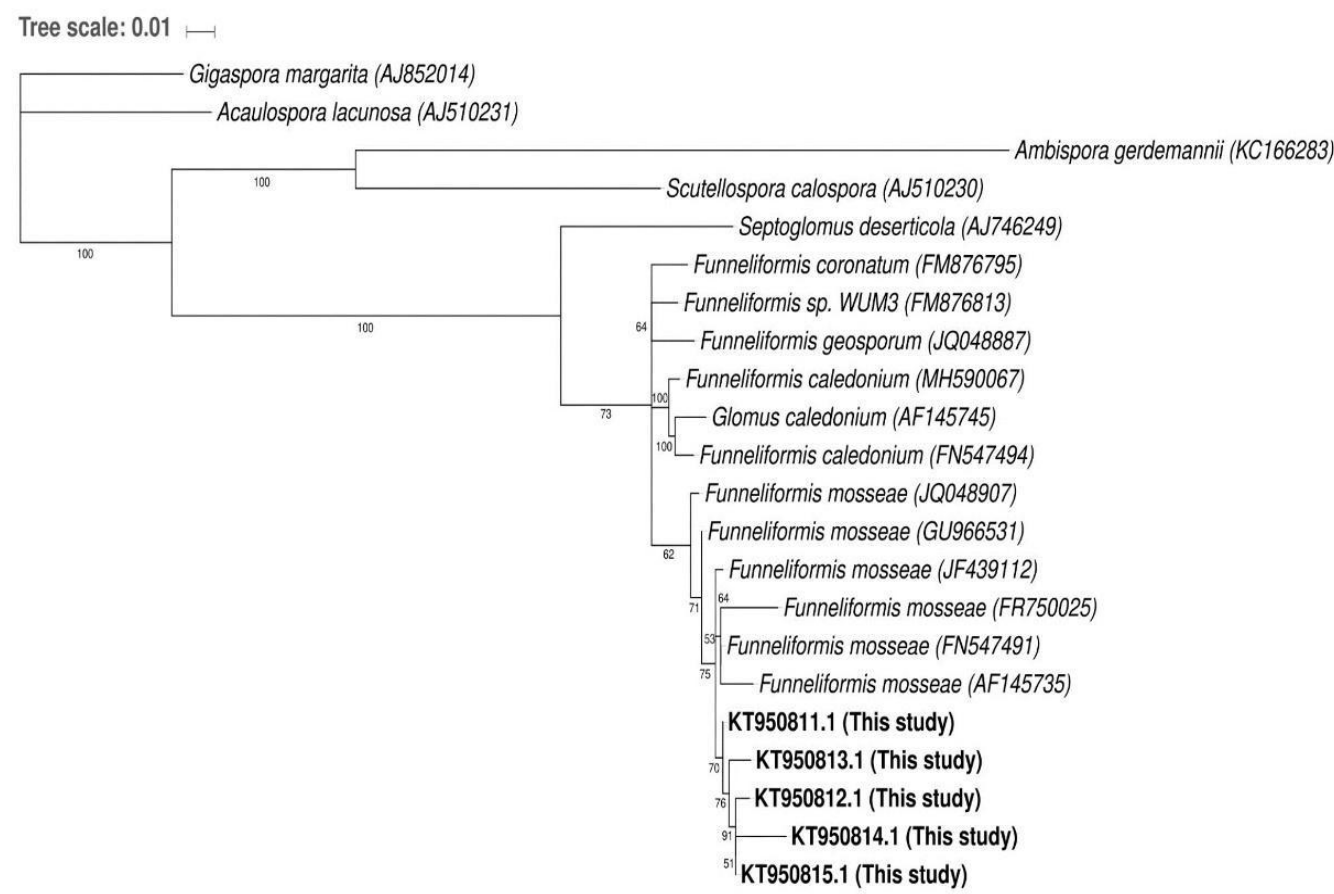

Figure 4. Phylogenetic tree constructed with a maximum parsimony analysis of taxa with the obtained SSCP sequences of closely related AMF species. References: the branches corresponding to partitions reproduced in less than 50\% of bootstrap replicates are collapsed. The percentage of replicate trees in which the associated taxa clustered together in the bootstrap test (100 replicates) is shown next to the branches. Sequences generated in this study were registered in GenBank under the following accession number: KT950811, KT950812, KT950813, KT950814 and KT950815.

The richness obtained from the SSCP strategy was higher than the one obtained from the spore morphology (Tables 1 and 2). The morphological analysis focused on the taxonomic determination of entire spores, while the SSCP strategy started with DNA extraction from soil where all genomic material could be extracted from both spores and other AMF structures (hyphae) in the soil. In this sense, even though it seemed that this could be the cause of the higher richness revealed by the SSCP approach in comparison to the morphological one, in a previous study [9] we determined that both the diversity and richness of AMF evaluated by the SSCP strategy did not differ between analysis from soil (spores + hyphae) or from previously isolated AMF spores. We did not know the causes of the lower richness revealed by the morphological approach; hence, future studies should focus on elucidating this matter.

The sequences obtained from the re-amplified bands of the polyacrylamide gel showed considerable similarity ( $>97 \%$ ) with the representative sequences of Funneliformis (= Glo$m u s)$ genus available in the databases. This genus was grouped separately from other AM fungal genera and was included as an outgroup (Figure 4). The SSCP revealed the presence of Funneliformis mosseae although this species was not detected by the morphological spore analysis. This result reinforced the importance of complementing classical morphological techniques with molecular ones such as the SSCP strategy for prospective AMF diversity studies.

Although the morphological analysis allowed a more comprehensive differentiation within an AM fungal genus than the molecular analysis, some difficulties related to the recognition of the juvenile, mature, and old spores of each species were frequently reported [18]. Regarding TC, only a low percentage of studies recommended it as a reliable method for AMF multiplication prior to morphological or molecular identification. Some authors argue that TC does not reflect in situ reality [19]; others [20] state that TC should not be used to assess AMF diversity whenever the richness is less than 21 species per site, whereas the sole use of direct analysis of field samples should be avoided if the total AMF 
richness is below that value. However, it was demonstrated [21] both by morphological and molecular methods that a considerable proportion of spores in the rhizosphere were dead despite their intact appearance. The authors then stated that using TC would give more reliable results for AMF diversity studies. Furthermore, it was also demonstrated that the denaturing gradient gel electrophoresis (DGGE) clustering analysis was reliable for the detection of AMF diversity after TC and that AMF diversity increased more significantly when combined with three host species (Trifolium repens, S. bicolor, and Zea mays) than with one host species grown alone [22]. DGGE is a strategy comparable to SSCP; however, the latter is sometimes more efficient at detecting different phylogenetic groups and less time-consuming for sample preparation [23]. Furthermore, the SSCP approach revealed the presence of $F$. mosseae, a glomoid species that remained hidden for the morphological methodology. This result is in accordance with new molecular results obtained by the next-generation sequencing approach applied to Puna soils of native Z. mays var. ocho-rayas and Solanum tuberosum var. chusqueña at Chaupi Rodeo, an Andean settlement located near the sites studied in this work [24].

\section{Materials and Methods}

\subsection{Study Area and Soil Sampling}

The study area is located in the floristic district known as "Puna Seca", Argentina. Two pristine sites were analysed: Abra del Cóndor (AC) $\left(22^{\circ} 53^{\prime} 23.5^{\prime \prime} \mathrm{S} ; 65^{\circ} 14^{\prime} 56.1^{\prime \prime} \mathrm{W}\right.$, $3870 \mathrm{~m}$ a.s.l., Salta Province) and Iturbe (It) $\left(23^{\circ} 00^{\prime} 06.8^{\prime \prime} \mathrm{S} ; 65^{\circ} 22^{\prime} 07.31^{\prime \prime} \mathrm{W}, 3370 \mathrm{~m}\right.$ a.s.l., Jujuy Province; Argentin). Thirty sub-samples of soil and roots from native grasses were collected at each site from an area of 1 ha at a depth of $15-20 \mathrm{~cm}$. Only plants of the grass family Poaceae were sampled to minimize the effect of the host species on the AMF communities. The climatic characteristics, soil properties, and grass species $[12,25,26]$ of the sampled sites are detailed in the supplementary information (Tables S1-S3).

\subsection{AMF Propagule Multiplication}

The collected soils were used as substrates to perform the trap cultures (TCs) using different trap plant species (TPS) as arbuscular mycorrhizal fungi (AMF) hosts (Tables 1 and 2, Figure S1). All seeds of the TPS were surface sterilized by immersion in $90 \%$ ethanol for $3 \mathrm{~min}$ and in 5\% $\mathrm{NaClO}$ for $1 \mathrm{~min}$. The TPS were grown in pots of $2 \mathrm{~kg}$ under controlled conditions: $12 \mathrm{~h}$ light $/ 12 \mathrm{~h}$ dark, $21{ }^{\circ} \mathrm{C}$, and at $60 \%$ of the soil waterholding capacity throughout the experiment. Each TC multiplication cycle was quintupled. At the end of each cycle, and regardless of the number of TPS used, all substrates were homogenised and used for subsequent analyses (Figure S1).

Soil samples from Abra del Cóndor (AC) were grouped into ACM1 and ACM2 according to the TC strategies, which differed both for the diversity of the TPS and the number and duration of the multiplication cycles. ACM1 and ACM2 included 1 and 2 culture cycles of 5 and 7 months, respectively (Table 1, Figure S1). Soil samples from Iturbe (It) were divided according to the treatments into ItM3-a1, It M3-a2, and It M3-a3 (Figure S1). The multiplication periods and the number of culture cycles were common to all treatments: 13 months divided into 3 cycles of 5, 6, and 2 months. The first and second cycles included the same TPS for all treatments. The third treatment used a different TPS for each treatment (Table 2, Figure S1).

\subsection{Glomoid AMF Diversity Assessed by Spore Morphological Approach}

AMF spores were extracted from TC substrates using the wet sieving method, for which they were successively passed through 250,125 , and $38 \mu \mathrm{m}$ sieves, and then centrifuged in a 50\% sucrose solution [2]. Only glomoid spores were morphologically studied since this was the only AMF group that could also be analysed with molecular tools. Spores were mounted onto slides using PVLG (polyvinyl alcohol-lactic acid-glycerol) both with and without a Melzer reagent. The taxonomic classification of Glomeromycota was carried out by microscopic observation of the spores, which were compared with the descriptions 
available in http:/ / www.amf-phylogeny.com/, http:/ / fungi.invam.wvu.edu/the-fungi/ species-descriptions.html (accessed on 7 July 2021) and [27]. Voucher specimens of spores and sporocarps were deposited in MICODIF-Unit 266-360-SNDB-UNSL (Sistema Nacional de Datos Biológicos-Universidad Nacional de San Luis, Argentina).

\subsection{Molecular Analysis of Glomoid AMF Diversity}

AMF genetic diversity was analysed with PCR-single strand conformation polymorphism (PCR-SSCP). The DNA was isolated from $0.25 \mathrm{~g}$ of each trap culture substrate (homogenised from replicates) obtained after the treatments previously described using the PowerSoil ${ }^{\circledR}$ DNA Extraction kit (MoBio, Germantown, MD USA) according to the manufacturer's instructions. Afterwards, nested PCRs were performed to amplify a fragment of the large subunit of the $28 \mathrm{~S}$ rRNA gene. PCR amplifications were run using an Eppendorf Thermal Cycler (Bio-Rad, Hercules, CA, USA). For the first reaction, $3 \mu \mathrm{L}$ of template (extracted DNA) were amplified by using $1 \mathrm{U}$ of the GoTaq ${ }^{\circledR}$ DNA Polymerase (Promega), its buffer, needed dNTPs, and the fungal specific primer pair LSU0061/LSU0599 [16] (5'-AGCATATCAATAAGCGGAGGA-3' /5'-TGGTCCGTGTTTCAAGACG-3'). The following program was used: an initial denaturation for $2 \mathrm{~min}$ at $94{ }^{\circ} \mathrm{C}$ was followed by 30 cycles of $1 \mathrm{~min}$ at $94{ }^{\circ} \mathrm{C}, 1 \mathrm{~min}$ at $53^{\circ} \mathrm{C}$ and $5 \mathrm{~min}$ at $72{ }^{\circ} \mathrm{C}$, and $7 \mathrm{~min}$ at $72{ }^{\circ} \mathrm{C}$. The second reaction was performed with $3 \mu \mathrm{L}$ of template (1:50 dilution of amplicons resulting from the first PCR reaction), $1 \mathrm{U}$ of the GoTaq ${ }^{\circledR}$ DNA Polymerase (Promega), its buffer, the corresponding dNTPs, and AMF specific primer pair LSUrk4f/LSUrk7r $[16,17]\left(5^{\prime}-\right.$ GGGAGGTAAATTTCTCCTAAGGC-3' $/ 5^{\prime}$-ATCGAAGCTACATTCCTCC- $\left.3^{\prime}\right)$. Nested PCR program was as follows: an initial denaturation of $2 \mathrm{~min}$ at $94{ }^{\circ} \mathrm{C}, 25$ cycles $(1 \mathrm{~min}$ at $94{ }^{\circ} \mathrm{C}, 1 \mathrm{~min}$ at $60{ }^{\circ} \mathrm{C}$, and $1 \mathrm{~min}$ at $\left.72{ }^{\circ} \mathrm{C}\right)$, and a final extension $\left(7 \mathrm{~min}\right.$ at $\left.72{ }^{\circ} \mathrm{C}\right)$. This primer pair was suitable for the SSCP analysis and targeted a sequence of $300 \mathrm{bp}$, including the LSUrDNA variable domain D1 from a broad spectrum of AMF species that belong to Funneliformis spp. (i.e., Funneliformis mosseae; F. caledonius and F. geosporus) and Rhizoglomus. Integrity and concentration of extracted DNA and size of PCR amplicons were checked by agarose gel electrophoresis (1.0\% w/v agarose; 100 V, $45 \mathrm{~min})$ using Gel $\operatorname{Red}^{\circledR}$ staining.

About $5 \mu \mathrm{L}$ of the PCR products generated by LSUrk4f and LSUrk7r primer pairs were analysed by the SSCP technique. The amplicons were denatured with $3 \mu \mathrm{L}$ of denaturing loading mixture (95\% deionized formamide, $0.05 \%$ bromophenol blue, $0.05 \%$ xylene cyanol FF and EDTA $20 \mathrm{mM}$ ) at $95^{\circ} \mathrm{C}$ for $5 \mathrm{~min}$, and immediately plunged into ice. Each sample was loaded into the $1 \mathrm{~mm}$-thick gel 0.5X $\mathrm{MDE}^{\circledR}$ (Cambrex, Rockland ME, USA), the run buffer consisted in 1X TBE (0.045 M Tris/borate, $0.001 \mathrm{M}$ EDTA). Electrophoresis was performed at e Dcode Universal Mutation Detection System (BioRad, USA) at $15{ }^{\circ} \mathrm{C}, 8 \mathrm{~W}, 300 \mathrm{~V}$ for $4 \mathrm{~h}$. The SSCP gels were silver stained following [28], scanned, and finally analysed. The protocols were performed as in previous studies $[9,16]$. The SSCP patterns (presence/absence and intensity of bands) were analysed using the Phoretix1DPRO software (Nonlinear Dynamics, United Kingdom). Only bands with an intensity $>0.1 \%$ of the total lane were considered for further analysis. All richness and diversity indices were calculated using the $0.1 \%$ threshold for relative abundances of single phylotypes (bands) because without such a detection limit these indices are not reliable [29]. Number and band intensity were used to calculate the ShannonWiener diversity $\mathrm{H}^{\prime}$ index [30] and AMF richness was indicated by the total number of bands detected.

One defined band per sample from the SSCP gel was excised, suspended in $30 \mu \mathrm{L}$ water ( 2 cycles of hot-freeze: $1 \mathrm{~h}$ at $60^{\circ} \mathrm{C}$ and frozen at $-20^{\circ} \mathrm{C}$ ), re-amplified (as described for second PCR reaction), purified (Wizard ${ }^{\circledR}$ SV Gel and PCR Clean-Up System), and sequenced (Macrogen). Homologous sequences to those obtained in this study were determined through BLASTn procedure at NCBI and MAARJAM (http:/ / maarjam.botany.ut.ee, accessed on 7 July 2021) databases. Phylogenetic analysis was carried out using Funneliformis sequences which were selected following the criteria of query coverage between 99 and $100 \%$, Maximun identity $>97 \%$, and the E values $>1 \times 10^{-100}$ (Table S4). Sequences 
from well-defined organisms were selected instead of sequences from unculturable organisms to develop a better understanding of sequence-based species identification of the Glomeromycota genus Funneliformis (= Glomus). Sequences that belonged to other Glomeromycota genera such as Septoglomus, Scutellospora, Ambispora, Acaulospora, and Gigaspora were included in the analysis as outgroups. All sequences were aligned using T-Coffee software (multiple sequence alignment: MSA), and a maximum-likelihood tree was performed using the PhyML 3.0. platform (HKY85 substitution model, SPR algorithm, 100 bootstraps) [31]. All sequences obtained in this study were deposited at NCBI Gene Bank under the accession numbers KT950811 (ACM1), KT950812 (ItM3-a1), KT950813 (ItM3-a2), KT950814 (ItM3-a3), and KT950815 (ACM2).

\section{Conclusions}

In this study, different strategies of multiplication of arbuscular mycorrhizal fungi (AMF) propagule indigenous to two pristine soils of the Argentine Puna (elevation over $3000 \mathrm{~m}$ a.s.l.) were evaluated. The diversity and richness of species with an emphasis on glomoid AMF were analysed, using both a morphological approach as well as a simple and low-cost molecular tool. Our results were compared with previous field AMF spore diversity reports at these sites, which confirmed the effectiveness of TC in detecting cryptic AMF species never before described for the Puna. Seven cryptic AMF species were identified by spore morphology (Funneliformis sp., F. geosporus, F. monosporus, Rhizoglomus microaggregatum, Septoglomus constrictum, and Sclerocystis sp.) and by sequencing ( $F$. mosseae). The generalist AMF identified included Funneliformis sp., F. geosporus, F. mosseae, R. microaggregatum, R. aggregatus, Sclerocystis sinuosa, and Septoglomus constrictum, while some rare species included F. monosporus and Sclerocystis sp. The combination of TPS used was crucial to detecting cryptic glomoid species. The SSCP in combination with the morphological approach, allowed to characterise the diversity of the indigenous glomoid AMF multiplied in TC from the studied sites. The results of this study seem to indicate that the TC approach played an important role in multiplying AMF propagules, and that increasing the number of multiplication cycles did not negatively impact the composition and richness of the glomoid AMF. Overall, we emphasized the importance of combining morphological and molecular strategies in diversity studies and the maintenance of AMF diversity through the variation of host plants and the application of long multiplication cycles for propagules multiplication.

Supplementary Materials: The following are available online at https://www.mdpi.com/article/ 10.3390/plants10091803/s1, Figure S1: Trap culture methodology applied to soil samples from the Puna Seca (Abra del Cóndor-Iturbe), Table S1: Environmental (climatic) characteristics of the Puna Seca (Abra del Cóndor-Iturbe) [25]. Table S2: Soil physicochemical characteristics at two elevations of the Puna [26,32]. Table S3: Dominant plant species sampled at two elevations of the Puna. Table S4: Results of BLASTn procedure and the criteria for selecting the homologous Funneliformis sequences used in the phylogenetic analysis.

Author Contributions: M.A.L. conceived and designed the project and the experimental work, made the sample collections, and was responsible for AMF morphological identification. F.C. and K.H.G. carried out the molecular methodology and the sequence analysis. E.M.C. and M.S.R.M. participated in sample processing, trap plant culture, and AMF morphological analysis. F.C., M.A.L., E.L., and K.H.G. interpreted the results and wrote the manuscript in collaboration with E.M.C., E.L. critically revised the document. All authors have read and agreed to the published version of the manuscript.

Funding: This research was funded by PROICO 2-2718 (MICODIF-FQBYF-UNSL), PIP 0424 (CONICET), and National INTA Project E2 2019-PD-E2-I037-002.

Institutional Review Board Statement: Not applicable.

Informed Consent Statement: Not applicable.

Data Availability Statement: The sequences data presented in this study are available in GenBank under the accession numbers (KT950811, KT950812, KT950813, KT950814, KT950815). 
Acknowledgments: Fernanda Covacevich and Mónica A. Lugo are researchers of Consejo Nacional de Investigaciones Científicas y Tecnológicas (CONICET), Argentina. The authors are very grateful to Microbiologist Hebe J. Iriarte (CPA of the technical staff of IMIBIO-CONICET -MICODIF) for preparing the figure that summarizes the trap culture methodology (Figure S1) and for improving the quality of all the images in this work. Finally, Matilde M. Crespo has our deepest gratitude for her corrections and improvements to the English language version of this manuscript.

Conflicts of Interest: The authors declare no conflict of interest.

\section{References}

1. Powell, J.R.; Rillig, M.C. Biodiversity of arbuscular mycorrhizal fungi and ecosystem function. New Phytol. 2018, 220, 1059-1075. [CrossRef]

2. Brundrett, M.; Bougher, N.; Dell, B.; Grove, T.; Malajczuk, N. Working with Mycorrhizas in Forestry and Agriculture; CSIRO: Canberra, Australia, 1996; p. 374.

3. Stürmer, S.L.; Bever, J.D.; Morton, J.B. Biogeography of arbuscular mycorrhizal fungi (Glomeromycota): A phylogenetic perspective on species distribution patterns. Mycorrhiza 2018, 28, 587-603. [CrossRef] [PubMed]

4. Trejo-Aguilar, D.; Lara-Capistrán, L.; Maldonado-Mendoza, I.E.; Zulueta-Rodríguez, R.; Sangabriel-Conde, W.; Mancera-López, M.E.; Negrete-Yankelevich, S.; Barois, I. Loss of arbuscular mycorrhizal fungal diversity in trap cultures during long-term subculturing. IMA Fungus 2013, 4, 161-167. [CrossRef]

5. Davison, J.; Moora, M.; Öpik, M.; Adholeya, A.; Ainsaar, L.; Bâ, A.; Burla, S.; Diedhiou, A.G.; Hiiesalu, I.; Jairus, T.; et al. Global assessment of arbuscular mycorrhizal fungus diversity reveals very low endemism. Science 2015, 349, 970-973. [CrossRef]

6. Hijri, M.; Sanders, I.R. Low gene copy number shows that arbuscular mycorrhizal fungi inherit genetically different nuclei. Nature 2005, 433, 160-163. [CrossRef] [PubMed]

7. Mathieu, S.; Cusant, L.; Roux, C.; Corradi, N. Arbuscular mycorrhizal fungi: Intraspecific diversity and pangenomes. New Phytol. 2018, 220, 1129-1134. [CrossRef] [PubMed]

8. Alguacil, M.M.; Roldán, A.; Torres, M.P. Assessing the diversity of AM fungi in arid gypsophilous plant communities. Environ. Microbiol. 2009, 11, 2649-2659. [CrossRef]

9. Thougnon Islas, A.J.; Hernandez Guijarro, K.; Eyherabide, M.; Sainz Rozas, H.R.; Echeverría, H.E.; Covacevich, F. Can soil properties and agricultural land use affect arbuscular mycorrhizal fungal communities indigenous from the Argentinean Pampas soils? Appl. Soil Ecol. 2016, 101, 47-56. [CrossRef]

10. Commatteo, J.G.; Consolo, V.F.; Barbieri, P.A.; Covacevich, F. Indigenous arbuscular mycorrhiza and Trichoderma from systems with soybean predominance can improve tomato growth. Soil Environ. 2019, 38, 151-161. [CrossRef]

11. Lugo, M.A.; Menoyo, E. Chapter 12: Southern Highlands: Fungal Endosymbiotic Associations. In Mycorrhizal Fungi in South America; Life Science Series, Fungal Biology; Pagano, M.C., Lugo, M.A., Eds.; Springer: Cham, Switzerland, 2019 ; pp. $217-255$. ISBN 9783030152277.

12. Lugo, M.A.; Ferrero, M.; Menoyo, E.; Estévez, M.C.; Siñeriz, F.; Anton, A.M. Arbuscular mycorrhizal fungi and rhizospheric bacteria diversity along an altitudinal gradient in South American Puna grassland. Microbiol. Ecol. 2008, 55, 705-713. [CrossRef]

13. Oehl, F.; Sieverding, E.; Ineichen, K.; Mäder, P.; Boiler, T.; Wiemken, A. Impact of land use intensity on the species diversity of arbuscular mycorrhizal fungi in agroecosystems of Central Europe. Appl. Environ. Microbiol. 2003, 69, 2816-2824. [CrossRef]

14. Songachan, L.S.; Kayang, H. Diversity of arbuscular mycorrhizal fungi associated with Flemingia vestita Benth. ex Baker. Mycology 2013, 4, 85-95. [CrossRef]

15. Liu, R.J.; Wang, F.Y. Selection of appropriate host plants used in trap culture of arbuscular mycorrhizal fungi. Mycorrhiza 2003, 13, 123-127. [CrossRef]

16. Kjøller, R.; Rosendahl, S. Detection of arbuscular mycorrhizal fungi (Glomales) in roots by nested PCR and SSCP (Single Stranded Conformation Polymorphism). Plant Soil 2000, 226, 189-196. [CrossRef]

17. Rosendahl, S.; Stukenbrock, E.H. Community structure of arbuscular mycorrhizal fungi in undisturbed vegetation revealed by analyses of LSU rDNA sequences. Mol. Ecol. 2004, 13, 3179-3186. [CrossRef]

18. Wetzel, K.; Silva, G.; Matczinski, U.; Oehl, F.; Fester, T. Superior differentiation of arbuscular mycorrhizal fungal communities from till and no-till plots by morphological spore identification when compared to T-RFLP. Soil Biol. Biochem. 2014, 72, 88-96. [CrossRef]

19. Säle, V.; Aguilera, P.; Laczko, E.; Mäder, P.; Berner, A.; Zihlmann, U.; van der Heijden, M.G.A.; Oehl, F. Impact of conservation tillage and organic farming on the diversity of arbuscular mycorrhizal fungi. Soil Biol. Biochem. 2015, 84, 38-52. [CrossRef]

20. Leal, P.L.; De Carvalho, T.S.; Siqueira, J.O.; Moreira, F.M.S. Assessment of the occurrence and richness of arbuscular mycorrhizal fungal spores by direct analysis of field samples and trap culture-A comparative study. Anais da Academia Brasileira de Ciências 2018, 90, 2359-2373. [CrossRef]

21. Sun, X.; Hu, W.; Tang, M.; Chen, H. Characterizing and handling different kinds of AM fungal spores in the rhizosphere. World J. Microbiol. Biotechnol. 2016, 32, 97. [CrossRef] [PubMed]

22. Yao, Q.; Gao, J.L.; Zhu, H.H.; Long, L.K.; Xing, Q.X.; Chen, J.Z. Evaluation of the potential of trap plants to detect arbuscular mycorrhizal fungi using polymerase chain reaction-denaturing gradient gel electrophoresis analysis. Soil Sci. Plant Nutr. 2010, 56, 205-211. [CrossRef] 
23. Hong, H.; Pruden, A.; Reardon, K.F. Comparison of CE-SSCP and DGGE for monitoring a complex microbial community remediating mine drainage. J. Microbiol. Methods 2007, 69, 52-64. [CrossRef]

24. Ontivero, R.E.; Voyron, S.; Risio Allione, L.V.; Bianco, P.; Bianciotto, V.; Iriarte, H.J.; Lugo, M.A.; Lumini, E. Impact of land use history on the arbuscular mycorrhizal fungal diversity in arid soils of Argentinean farming fields. FEMS Microbiol. Lett. 2020, 367, 1-11. [CrossRef] [PubMed]

25. Martínez Carretero, E. La Puna Argentina: Delimitación general y división en distritos florísticos. Boletín de la Sociedad Argentina de Botánica 1995, 31, 27-40.

26. Panigatti, J.L. Argentina: 200 Años, 200 Suelos; INTA: Buenos Aires, Argentina, 2010; p. 345. Available online: https://inta.gob.ar/ sites/default/files/script-tmp-inta-200-suelos.pdf (accessed on 7 July 2021).

27. Wijayawardene, N.N.; Hyde, K.D.; Al-Ani LK, T.; Tedersoo, L.; Haelewaters, D.; Rajeshkumar, K.C.; Deng, C. Outline of fungi and fungus-like taxa. Mycosphere 2020, 11, 1060-1456. [CrossRef]

28. Benbouza, H.; Jacquemin, J.M.; Baudoin, J.P.; Mergeai, G. Optimization of a reliable, fast, cheap and sensitive silver staining method to detect SSR markers in polyacrylamide gels. Biotechnol. Agron. Soc. Environ. 2006, 10, 77-81.

29. Höfle, M.G.; Kirchman, D.; Christen, R.; Brettar, I. Molecular diversity of bacterioplankton: Link to a predictive biogeochemistry of pelagic ecosystems. Aquat. Microb. Ecol. 2008, 53, 39-58. [CrossRef]

30. Cui, J.; Bai, L.; Liu, X.; Jie, W.; Cai, B. Arbuscular mycorrhizal fungal communities in the rhizosphere of a continuous cropping soybean system at the seedling stage. Environ. Microbiol. 2018, 49, 240-247. [CrossRef]

31. Guindon, S.; Dufayard, J.F.; Lefort, V.; Anisimova, M.; Hordijk, W.; Gascuel, O. New algorithms and methods to estimate maximum-likelihood phylogenies: Assessing the performance of PhyML 3.0. Syst. Biol. 2010, 59, 307-321. [CrossRef]

32. Bray, R.H.; Kurtz, L.T. Determination of total, organic and available forms of phosphorus in soils. Soil Sci. 1945, 59, 39-45. [CrossRef] 